Published as: Ghasemi, S; Karami, E; Azadi, H. (2013). Knowledge, attitudes and behavioral intentions of agricultural professionals toward genetically manipulated (GM) foods: A case study in Southwest Iran. Science and Engineering Ethics, vol. 19(3): 1201-1227.

\title{
Knowledge, attitudes and behavioral intentions of agricultural professionals toward genetically manipulated (GM) foods: A case study in Southwest Iran
}

\begin{abstract}
While there has been a number of consumers' studies looking at factors that influence individuals' attitudes and behavior toward GM foods, few studies have considered agricultural professionals' intentions in this regard. This study illuminates agricultural professionals' insights toward GM foods in Southwest Iran. A random sample of 262 respondents was studied. The results indicated that the majority of the respondents had little knowledge about GM foods. They perceived few benefits or risks of GM foods. Their perceived benefits and trust in individuals and institutions had positive impacts on the behavioral intentions of the agricultural professionals. The results also revealed that the low knowledge level of the respondents had a negative impact on the behavioral intentions toward GM foods. This state of affairs is problematic, either GM foods have serious problems or the knowledge conveyed to the Iranian agricultural experts is inappropriate. We recommend a well defined communication strategy to provide
\end{abstract}


information in such a way that allows individuals to feel adequately informed about GM foods. Furthermore, the development of trust and knowledge regarding GM foods can be greater when risk analysis frameworks are transparent, risk assessment methodologies are objective, all stakeholders are engaged in the risk management process, and risk communication focuses on consumers.

Keywords: GM foods, knowledge, attitude, agricultural professionals, gatekeepers.

\section{Introduction}

Despite general agreement among writers that conventional agriculture is not sustainable (Pretty 1995; Rasul and Thapa 2003; Wheeler 2008), there is little consensus on possible paths to sustainability. The paths are diverse (Wheeler 2008) and often conflicting (Rigby 2001). Some suggest that biotechnology and GM foods may provide solutions to the current problems of conventional agriculture (Wheeler 2005). Although this position is not without opposition, GM foods are supported by many governments and scientists (Pindstrup-Andersen and Schibler 2001; Cohen and Paarlberg 2002; King 2007) as a viable road toward sustainability and providing food for the ever increasing population (Peters 2003).

Historically, genetic experiments have been made by humans for centuries in the form of crossing plants and animals with the purpose of making them better for industrial uses and human consumption. At the present time, the genetic modifications are being done in a scientific way, by the use of advanced techniques which manipulate and multiply selected genes even when those genes have been derived from a species that is different from the recipient species. Such modifications are the key concept of GM crops (Sheikhha et al. 2006). The crops first appeared commercially in the mid- 
1990s to what seemed a bright and promising future. GM technology lets scientists combine genes of totally unrelated species of plants, micro organisms and animals (Lobb et al. 2007). The crops are currently a hot topic in both academic and political circles for their implications for food security (Azadi and Ho 2010), economic growth and income distribution, human health, the environment, and agricultural trade (Zhong et al. 2002). These GM products have caused many controversies among scientists as follows.

GM foods are considered to enhance agricultural sustainability. Resistance to pests and the herbicides used to control weeds have resulted in these new crops becoming popular with farmers so that millions of acres are being planted by them in the new millennium (Moon and Balasubramanian 2001; Huang et al. 2004; Martinez-Poveda et al. 2009). In 2008, GM crops were grown commercially by 13.3 million farmers on 125 million hectares spread across 25 countries. The world's top five producers -the United States, Argentina, Brazil, India, and Canada- account for at least 90\% of global GM cultivation; of this, more than half is cultivated in the United States (ISAAA 2009).

GM products have caused many controversies among scientists as well (Azadi and Ho 2010). Advocates of the use of genetic engineering techniques in food contend that this new biotechnology promises higher yields (Grunert et al. 2000; Uzogara 2000; Moon and Balasubramanian 2001; Fritz et al. 2003; Huang et al. 2004; Chen and Li 2007; Martinez-Poveda et al. 2009), lower prices (Huang et al. 2004; Chen and Li 2007; Soregaroli et al. 2003), less need for the use of both pesticides and herbicides (Grunert et al. 2000; Moon and Balasubramanian 2001; Huang et al. 2004; Martinez-Poveda et al. 2009), longer shelf time (Zhong et al. 2002); higher resistance to dry and excessive wet weather (Sheikhha et al. 2006), improved nutritional quality and taste (Grunert et al. 
2000). Such benefits would promote agricultural productivity and hence increase food supplies for the growing population (Grunert et al. 2000). Increased efficiency would also reduce costs for farmers and prices for consumers (Chen and Li 2007) ${ }^{\mathrm{a}}$. On the other hand, some individuals see risks ranging from general concerns to specific fears in the use of biotechnology in food production. The general concerns include environmental pollution (Moseley 1999; Frewer et al. 2000; Zhong et al. 2002), crosspollination (Moseley 1999; Martinez-Poveda et al. 2009), the possible creation of new viruses and toxins, limited access to seeds due to the patenting of GM plants, the threat to crop genetic diversity (Moon and Balasubramanian 2001; Martinez-Poveda et al. 2009), religious, cultural, and ethical concerns (Thompson 1999; Uzogara 2000; Mathison 2001; Moon and Balasubramanian 2001; Chen and Li 2007; Wheeler 2009), and also unknown consequences (Uzogara 2000).

Specific dark thoughts that haunt individuals' minds include the alteration in the nutritional quality of foods, potential toxicity, possible antibiotic resistance from GM crops (Moseley 1999) and potential allergenicity and carcinogenicity from consuming GM foods (Martinez-Poveda et al. 2009). Critics also raise the possibility of gene transfer between GM and non-GM crops (Aerni 2001), a process that could have unpredictable results (Uzogara 2000).

In total, the potential benefits and risks associated with GM foods go beyond food security and safety and also encompass issues such as the impact of GM products on the environment. Potential consumers may also be concerned about the moral and ethical aspects of GM technology (e.g. concerns about the (un)naturalness of gene technology, "playing God"; or the welfare of transgenic animals). It is likely that these different considerations affect the consumers' acceptance of GM foods in different ways. 
The study of consumers' attitudes ${ }^{\mathrm{b}}$ toward GM crops across cultures and regions in the world has been of great interest (Bredahl 2001; Moon and Balasubramanian 2001; Soregaroli et al. 2003; Chen and Li 2007). European consumers have resisted GM foods since the commercial introduction of biotech seeds in the early 1990s. A few studies have shown that European consumers' attitudes toward GM foods are negative (Bredahl et al. 1998; Verdurme and Viaene 2003; Wheeler 2008; 2009; Martinez-Poveda et al. 2009; Teisl et al. 2009). Numerous opinion polls, with the Eurobarometer surveys (Eurobarometer $2001 ; 2002 ; 2004 ; 2005$ ) as the most widely noted, have shown that the consumers do not like the idea of GM organisms in their food. In contrast, some studies detect that American consumers are optimistic about the possible benefits of GM foods, but they are also concerned about their associated health, safety and harmful ecological consequences (Hossain et al. 2002; Grunert et al. 2003; Onyango et al. 2003; Verdurme and Viaene 2003).

Although there have been a number of consumers and farmers' studies looking at knowledge, attitude and behavior with regard to GM foods in both developed (Boccaletti and Moro 2000; Chern et al. 2002; Papastefanou et al. 2003; Cook et al. 2002; 2003; Frewer et al. 2004; James 2004; Cardello et al. 2007; Shehata and Cox 2007; Wheeler 2008; Martinez-Poveda et al. 2009) and developing countries (Chen and Li 2007; Hu and Chen 2008; Aerni 2005; Huang et al. 2006; Sheikhha et al. 2006), almost no studies have considered the factors that influence the attitudes of agricultural professionals. Some studies have focused on expert-lay discrepancies. For instance, Hansen et al. (2003) studied psychological and social scientific research on expert-lay attitudes toward food risks. In their study, many experts (including scientists, food producers and public health advisors) regarded public unease about food risks as 
excessive. They found that the expert-lay discrepancy is often attributed to a knowledge deficit among lay people. In Sjoberg's (2008) survey study on the public and experts, the latter perceived fewer risks and more benefits for GM foods and were throughout much more positive to the foods than the former who doubted whether there was sufficient knowledge of the crucial properties of such foods. Also, in a study by Savadori (2004) who investigated expert-lay judgments when the issues are examined from the viewpoints of some 16 different aspects of biotechnology and its applications, some significant expert-lay discrepancies were found. The public found all biotechnology applications more risky than experts who significantly and systematically perceived the food and medical applications of biotechnology as less harmful and more useful. They concluded that such discrepancies may be affected by the nature of the hazard.

Agricultural Professionals as GM Crops' Gatekeepers

In each society, there is a small number of individuals, called gatekeepers, who may impact others' adoption decisions and, therefore, may influence the diffusion of a given innovation (Tornatzky and Fleisher 1990). In the diffusion literature, gatekeepers are known as "innovators, intermediators, helpers, adapters, opinion leaders, brokers, or facilitators" (Metoyer-Duran 1993) who can frequently influence others' attitudes or behavior (Rogers and Kincaid 1981). For Rogers (2003), gatekeepers are willing to experience new ideas. Consequently, they should be prepared to cope with a certain level of uncertainty about innovations. They normally deal with the uncertainties by relying on their high level of information, knowledge and technology. Collecting and 
disseminating information to members of other societies make them highly connected to external networks as well. Accordingly, they are expected to have a large number of contacts with external sources of information (Rogers and Agarwala 1976).

Contact with gatekeepers is expected to influence an individuals' utilization decisions, however, this does not necessarily mean that a gatekeeper always promotes a given innovation. Indeed, a negative gatekeeper might also inhibit the diffusion of an innovation. While positive gatekeepers serve both as role models and sources of information about a controversial innovation (e.g. GM foods), according to LeonardBarton (Leonard-Barton 1985), negative gatekeepers only provide information.

In Iran, with the goal of increasing the yield of agricultural production but also improving the resistance of some strategic crops to the main production challenges (e.g. drought and pest) in the country, GM crops are being introduced to the agricultural sector though almost no GM crops are growing in the country yet. Accordingly, the crops are not yet cultivated and produced at a large scale so that they can be presented at the level of the market. Hence, farmers and consumers do not have much information and experience with these crops and therefore cannot be regarded as the subject of this study. The only group that is becoming more informed and experienced with the crops are the agricultural professionals. This group is now very busy with the risk assessment of GM technology before recommending farmers to cultivate GM crops and consumers to consume GM foods. Accordingly, the group is regarded as gatekeepers of GM foods and this study is an attempt to understand their attitudes toward such foods.

Objectives 
The aim of this study was to explore the agricultural professionals' knowledge, attitudes and their behavioral intentions toward GM foods and to develop a model that can explain and predict the agricultural professionals' attitudes and their purchase intentions with regard to GM foods in Southwest Iran. 


\section{Research Framework}

According to Bredahl (1998) and Costa-Font et al.'s (2008) purchase intention models and Verdurme and Viaene's (2003) attitude and behavior model, the consumer's purchase intention toward GM foods (behavioral intention) is determined by the perceptions of risk, benefits and ethics of applying gene technology to produce food products. In turn, beliefs about the (potential) risks, benefits and ethics are strongly explained by consumer knowledge (Bredahl 1998; Cook et al. 2002; Verdurme and Viaene 2003; Chen and Li 2007; Costa-Font et al 2008). Siegrist (2000) suggests that public attitudes toward emerging technology such as gene technology are mainly driven by individuals' trust in those institutions that promote the technology and regulate its risks. Therefore, social trust should not be ignored in the conceptual research framework of the consumer's purchase intention toward GM foods. Fig. 1 presents the theoretical framework of this study about the agricultural professionals' purchase intention toward GM foods.

[insert Fig. 1]

Knowledge

Consumers' knowledge about GM technology in general and GM foods in particular, plays some role in determining consumers' risk and benefit perception, and eventually in their attitudes toward GM foods (Verdurme and Viaene 2003). According to Fishbein's multi-attribute model (Costa-Font et al. 2008), knowledge about a specific GM product is essential in order to shape the attitudes toward it. Some empirical studies 
(Boccaletti and Moro 2000; Moon and Balasubramanian 2001) have shown a direct association between knowledge and attitudes revealing a direct correlation between knowledge about GM technology and support to GM applications. Other studies (Chen and Li 2007) suggest that even if the public knowledge in the field of biotechnology increases, people are still less optimistic about GM foods. A few authors such as Baker and Burhan (2001) and Deodhar et al. (2008) have stated that an increase in the knowledge about GM foods implies a more positive attitude toward them and greater willingness to buy them. However, results obtained by Chen and $\mathrm{Li}$ (2007) and Boccaletti and Moro (2000) are the opposite. They showed that knowledge has a negative effect on the perception of these products. Wheeler (2009) found that scientists who are advocates or tacit supporters may believe that they are "right" because they have greater knowledge. She posits that increased knowledge should make the professionals' thoughts more optimistic. Thereby, the more professionals spend time researching genetic engineering, the more likely they will have a positive attitude toward it.

Trust

Consumers often need social trust to cope with the lack of knowledge about a new technology (Siegrist et al. 2007). Social trust refers to people's willingness to rely on experts and institutions in the management of risks and technologies. When people cannot directly assess the benefit and risks of GM foods, they have to rely on information provided by experts or other resources. Given the fact that people often have very limited knowledge of gene technology, the importance of trust should be no 
surprise. In their study, Chen and $\mathrm{Li}$ (2007) and Siegrist (2000) found trust in institutions that use gene products has a positive impact on the perceived benefit and a negative influence on the perceived risk of the products. Furthermore, the perceived benefits and risks determine the acceptance of biotechnology. In other words, trust has an indirect influence on the acceptance of the technology.

Perceived Benefits and Risks

Bredahl et al. (1998) developed a more detailed model to explain the "bottom-up" consumers' attitude toward GM foods, which states that attitudes toward GM food technology are defined by means of a weighted sum of attitudes toward each product and its corresponding process. Therefore, each attitude depends on the overall perceived risks and benefits associated with the product and process, respectively. The model has empirically been supported by some studies such as Moon and Balasubramanian (2001), Grunert et al. (2003) who state that consumers associate, on the whole, more negative than positive attributes to agro-biotechnology. Frewer and Shepherd (1995) found that the perceived risks and benefits were the best predictors for summative attitudes among British consumers toward GM foods.

Moon and Balasubramanian (2001) emphasise that consumers will only accept the new food when tangible benefits increase for them. They feel that this process will be possible only through effective information and educational programs that promote the positive attributes of agro-biotechnology.

It seems that cross-country differences also exist in relation to consumers' risks and benefits perceptions toward GM foods. For example, while Han and Harrison (2004) 
believe that consumers' perception depends on information, the credibility of the government and cultural preferences, Grunert et al. (2003) conclude that the European consumers' attitude toward the use of GM foods is not influenced by the provided information. They suggest that the negative attitude toward these foods would be difficult to change by means of information alone, although experience with products which involves benefits from their consumption could modify it. In his study on European citizens, Bredahl (2001) concluded that Danish, German and British consumers identified risk as an obstacle for the perception of benefits associated with GM foods, whereas in the Italians' view risk and benefit had a clear-cut compensatory relationship. In sum, consumers do not perceive GM technology as being a onedimensional skill.

\section{Perceived Ethics}

Ethical dilemmas surface when considering GM. Scientists can be seen as "playing God" (Moseley 1999); genetic manipulation breaches the natural boundaries that have evolved among species (Connor and Siegrist 2010). Such concerns are greater if animal or human DNA, rather than microorganisms or plants, are involved (Frewer et al. 1998). For Christians, the main concern is about the integrity of God's creation and the relationship of humanity with God (Mathison 2001). Muslims and Jews focus on their dietary codes which require that GM foods do not contain genes from unclean animals (e.g., pigs) (Thompson 1999).

Ethical considerations also arise: genetic engineering is expensive and will not be available to "poor" farming communities (Azadi et al. 2011a) and may even distort the 
economies of third world countries (Moseley 1999). One final ethical concern is related to the right to choose freely as consumers. For example, vegetarians should be able to choose or avoid food products produced by GM plants to which animal genes have been transferred (Verdurme and Viaene 2003).

\section{Research Method}

This survey was designed in 2008 to highlight agricultural professionals' knowledge, attitudes and behavioral intentions about GM foods. The population of this study consisted of agricultural professionals including ${ }^{\mathrm{c}}$ agricultural researchers and experts $^{\mathrm{d}}$. The researchers work in the Agricultural Research Center while the experts work in Rural Services Centers at county or provincial level. Both groups are employed by the Fars Agricultural Organization in the Fars province in Southwest Iran. The main reason why this organisation was studied is its stature as the most pioneering agricultural organization in the country. Furthermore, the province has been the most important productive region in producing strategic crops in the country.

Using a stratified random sampling method, 262 respondents were randomly selected for this study. The sample size was determined using the approach provided by Patton (2002). Since no information on population proportions was available before sampling, proportional allocation with two strata "agricultural experts" (75 percent) and "agricultural researchers" (25 percent) was used.

Data for this study were collected using a structured questionnaire. The face validity of the questionnaire was confirmed by a panel of experts. Several perceptional scales have been constructed in this project. Each scale includes several perception questions 
which all had an ordinal ranking answer (from 1-5). The summation of the answers to all questions for each scale was computed as the score of that scale. Using SPSS software (version 16), the reliability of the different questions used for each scale ${ }^{\mathrm{e}}$ was tested by the estimation of Cronbach's alpha coefficients. The coefficients showed higher than acceptable rates for all the scales used in the study (Table 1).

[insert Table 1]

The response rate (Baruch and Holtom 2008) was complete $(\mathrm{RR}=100 \%)$ since all the interviews were personally conducted by the first author, a process which took 3 months.

\section{Results and Discussion}

Respondent's Demographic Attributes

Table 2 represents a cross-section of the Iranian agricultural professionals in Fars province studied in this research.

\section{[insert Table 2]}

As shown in the table, 11.3 percent of the professionals are female and 88.7 percent are male. Most of them (66.1\%) are middle aged with an average of 38.84 years. The respondents mostly hold bachelor (58.9\%) and master $(25.1 \%)$ degrees. The majority self-identified as "agricultural expert" (62.6\%) and "researcher" (24.1\%). More than half $(50.8 \%)$ of the respondents have at least 14 years professional experience and a monthly income of $\$ 600$. 
Awareness and Knowledge about GM Foods

The first question tested the ten issues as shown in Table 3. The first issue was whether "GM crops are the same as conventionally cross-bred crops", which is false. As Table 2 shows, 23.8 percent of the respondents answered this question correctly while 76.2 percent answered incorrectly. It means that most of the respondents think that GM foods are the same as hybrid crops.

\section{[insert Table 3]}

The second issue was "GM foods are the same as organic foods", which is false. Almost two-third (63.7 per cent) of the respondents answered the second issue correctly, while the rest (36.3 per cent) answered incorrectly.

The third issue asked whether "GM crops are produced by taking genes from plant and animal species and transferring them into plants", which is true. Two-third (66.5 per cent) of the professionals answered this issue correctly and one-third (33.5 per cent) answered incorrectly. Much awareness is focused on the fourth issue; i.e., "some preferred features can be created in products by gene transfers", which is true. Most of the respondents (90.5 per cent) answered the fourth issue correctly, and the rest $(9.5$ percent) answered incorrectly.

The fifth issue was “non-GM foods don't contain genes, while GM foods do", which is false. Nearly, two-thirds $(62.7 \%)$ of the professionals answered this issue correctly and around one-third (37.3\%) answered incorrectly. The sixth issue questioned whether "it is impossible to transfer animal genes into plants", which is false. Here, one-third $(33.7 \%)$ of the respondents answered correctly and two-third (66.7\%) answered incorrectly. 
There is less awareness toward the seventh issue; i.e. "tomato modified by fish genes would taste fishy" which is false. Less than half (43.9 percent) of the professionals responded on this issue correctly while more than half (56.1\%) answered wrongly.

The eighth issue asked whether "GM foods can be distinguished from non-GM", which is false. Almost two-thirds (64.4 percent) of the respondents answered this question correctly and the rest (35.6\%) answered incorrectly.

The ninth issue questioned whether "all processed foods are made by using GM products", which is false. The majority of the respondent (80.5 percent) answered this issue correctly and 19.5 percent answered wrongly. The tenth and last issue asked whether "recently Iran is also applying GM technology to produce crops", which is true. Almost two-third (65.5\%) of the respondents answered to the last issue correctly and one-third (34.5\%) answered incorrectly.

The above findings show that most of the respondents ${ }^{\mathrm{f}}$ hold some valid knowledge toward GM crops. This is in contrast with other studies that do not conclude the same though they have mainly studied consumers or laypersons (and not professional experts). For example, Boccaletti and Moro (2000) concluded that the majority of their respondents do not have enough knowledge about GM crops. Shehata et al. (2007) in a study in Hawaii also concluded that the majority of their respondents have little or no knowledge regarding GM crops. Two other studies in China (2002) and the US (2004) also showed that people do not have much information regarding such crops whilst Hoban (1998) believes that the consumers' knowledge in the US regarding these crops is increasing. Yet, $\mathrm{Hu}$ and Chen (2004) found that most of the Chinese consumers cannot recognize GM from non-GM crops. 
One reason can be that the respondents in the aforementioned studies are end-users of GM crops who are public consumers while the respondents of our study are "gatekeepers" who are also expert consumers. This conclusion can be supported by Hossain et al. (2003) who showed that most of the Bangladeshi "agricultural experts and researchers" have broad information regarding these crops and most of them can even precisely define GMOs.

Trust in Individuals and Agencies

As GM is a new technology in Iran and public awareness of this innovation is not high, it is important to know which information resources are being used by people and how trustworthy they are in the eyes of public.

The respondents were asked to describe how much they trust information received from different stakeholders and institutions, including scientists and researchers; agricultural decision makers; the government; the Iranian Standard Institute; the person in charge of family shopping; physicians; Agricultural Support Services Company; food dealers; and policy makers. Using a five point Likert scale (from " 1 : fully disagree" to "5: fully agree"). Scores were summed and the average score of trust was 13.16. As shown in Table 4, the most trustable information resources for the respondents are "the person in charge of shopping in the family", "physicians", "government" and "scientists and researchers", with the total percentages (for items agree and fully agree) of 73.3, 73.2, 64.5 and 63.6, respectively, whereas the least trustable resources are "the Iranian Standard Institution", “agricultural decision makers", “Agricultural Support Services Company" and "policy makers", with the total percentages (for items disagree and fully disagree) of 54, 43.2, 34.7 and 44.7, respectively. 


\section{[insert Table 4]}

The above findings show that after "the person in charge of shopping in the family", the people who are expected to be most aware in a society can be trusted the most with regard to GM foods. Several studies (Fritz et al. 2003; Wingenbach et al. 2003; Aerni 2005) support our findings showing that "scholars" and "well-known people in society" are respectively the most and least trustable people to be consulted on GM crops. Like physicians in our study, Hoban (2001) showed that non-governmental health experts are the most trustable people in this regard. Our findings also show that the third most trustable information resource is government. This finding can be supported by $\mathrm{Hu}$ and Chen (2004) and Xi and Harris (2006) who showed that the most trustable people for consulting on GM crops come from government. Trail et al. (2004) also showed that the Americans have most trust in government to receive the information regarding GM crops while the Europeans find the environmentalists as the most trustable in this regard. In fact, because the professionals find themselves as government employees, through validating governmental information resource, they might (unconsciously) validate themselves.

\section{Perception toward GM Crops’ Benefits}

The respondents' perceptions toward GM crops' benefits are shown in Table 5. As shown in the table, considering the possible range (4-20) of the perceptions, the respondents' understanding of such advantages is moderate $(\bar{X}=14.07)$.

\section{[insert Table 5]}

Less than half $(43.1 \%)$ of the respondents understand the environmental benefits of 
GM crops whereas more than one-third (36.3\%) do not have any sharp opinion in this regard and still need more information to claim their clear belief. One-third of the respondents $(35 \%)$ however, are optimistic to the idea that GM crops reduce the production costs. With regard to "less use of chemical inputs" and "improving seeds" quality" by using GM crops, almost two-third of the respondents "agree" or "fully agree" with such benefits (63.3\% and 63.9\%, respectively). Most of them (77.5\%) also believe that GM crops are more resistant to drought and pests. Furthermore, 77.9 percent of the respondents believe that the storage shelf-time of GM crops is longer than other crops. However, almost two-third $(61.2 \%)$ of the respondents disagree with the better taste, color, shape and nutrients' quality of GM crops while 35 percent did not have any clear idea about the lower production costs, and 49 percent about shorter growth times of these crops.

The above findings show that the respondents are mostly positive toward the capabilities of GM crops, however, they do not find the GM foods' features better than the non-GM's. The findings can be supported by the results of Cook and Fairweather's (2003) study that showed that the farmers in New Zealand have positive attitudes toward GM crops. They mention that the reason mostly is that the respondents found more advantages (mainly higher yields and income) than disadvantages for these crops. However, James (2004) believes most American consumers are not able to judge whether such crops are useful or harmful. In Italy, as reported by Soregaroli et al. (2003), although most of the consumers consider higher yields for GM crops, they do not consider them to be of better quality. On the contrary, in Iran, Sheikhha et al. (2006) concluded that most of the consumers consider better quality for GM crops but they are afraid of the unknown consequences of these crops. 


\section{Perception toward GM Foods' Risks}

The respondents' perceptions toward GM foods' risks (mainly human health and environmental impacts) are shown in Table 6. Considering the possible range (4-20) of

the perceptions, the average of the perceptions is moderate $(\bar{X}=13.27)$. In other words, the respondents consider relative risk for such foods: $42.5 \%$ of the respondents "disagree" and "fully disagree" with considering GM crops as a threat to natural genetic balance; $78.5 \%$ believe that producing GM crops causes the transformation of safe species to unsafe; and $86.4 \%$ think that such crops create new bacteria and viruses. Thereby, they mostly judge these crops as a threat to the environment. As for a threat to human health, $38.6 \%$ of the respondents "agree" and "fully agree" that GM technology creates mutation in human genes; $86.4 \%$ believe that the crops are created based on the considerations of genetic engineers; $41.6 \%$ think the consumption of GM crops increases human resistance to antibiotics, and $43.5 \%$ believe that such foods cause human mutation.

\section{[insert Table 6]}

Furthermore, $41.8 \%$ of the respondents consider GM crops as a threat to useful insects; $15 \%$ believe this technology creates a conflict between rich and poor farmers; and $47.7 \%$ suspect undesirable cross-pollinations.

The above findings show that the respondents consider some risks for GM crops. The findings can be confirmed by Trail et al.'s (1999) study in the US, France and England who pointed to the risks of these crops for human and environmental health. In their study, understanding the GM crops' risks was considered as the most important factor that can influence individuals' behaviour. Chern et al. (2002) found that 50 percent of 
American consumers believe GM crops are risky for human and environmental health. This finding can also be confirmed by Hossain et al.'s (2003) study in Bangladesh that showed that in the view of consumers, the most important risk of using GM crops is related to human and environmental health. Furthermore, they also considered some other consequences of using these crops; i.e., vanishing flora and fauna, and creating natural catastrophes.

\section{Ethical Concerns about GM Foods}

The application of GM technology has caused serious ethical concerns (Knight 2009). It is therefore important to know whether or not agricultural professionals would find GM technology ethical. Table 7 shows the perceptions of professionals about ethical aspects of GM crops. As shown in the table, considering the possible range (4-20) of the perceptions, the average of these perceptions $(\bar{X}=12.87)$ falls around the mean.

\section{[insert Table 7]}

Most of the respondents $(83.8 \%)$ "disagree" and "fully disagree" with the statement that "Gene manipulation is interfering in God's creation and should not be permitted". Also, $71.3 \%$ reject the following statement that "If there were any better way for crops to be created, God would create them in that way". The results also show that $71 \%$ of the professionals do not consider gene manipulation as one of the main reasons for the current health crises, while $68.9 \%$ believe that "gene manipulation is not ethical as it might create some disorders in both human and animals".

Less than half of the respondents (44.2\%) "agree" and "fully agree" with the issue that "Consuming lamb products is not religiously permitted if they are produced by 
gene transfer from pork". This means that, as the respondents are Muslims, they would consider the produced meat in this process, still as pork meat which is forbidden. However, $38 \%$ still have doubt about the issue and therefore do not have a clear idea in this regard. The rest (17.9\%) believe the manipulated product is lamb and not pork anymore. The results also show that more than one-third of the respondents $(35.7 \%)$ "agree" and "fully agree" with producing GM foods if they can reduce poverty, hunger, and malnutrition.

All in all, the respondents are not very critical in ethical issues. This finding is in line with Fritz et al.'s (2003) study who found that both adult and youth respondent groups considered religious/ethical concerns as the least important obstacle to their acceptance of biotechnology productions. Also, in the study by Eurobarometer (2005), citizens in Italy, Portugal and Turkey seem somewhat less preoccupied by the issue of ethics although other Europeans would like to impose a balance between ethics and scientific progress. In another study by Eurobarometer (2002) however, most respondents disagree that GM foods are useful, agree that they are risky, find them morally unacceptable and are not prepared to support them. Moseley (1999) found that social acceptance of GM foods is not uniform in developed countries. The consumers' concerns can be based on ethical considerations (scientists "playing God") or safety worries ("more evaluation needs to be done"). Furthermore, there are some ethical concerns about scientists "playing God" by tinkering with the stuff of life, that genetic manipulation breaches the natural barriers and boundaries among species which nature has setup through the process of evolution, and that genetic manipulation distorts mankind's relationship with the rest of nature (Moseley 1999). Furthermore, people may perceive GM foods as unnatural, and consequently, they may have moral and 
ethical concerns that influence their perception of gene technology (Connor and Siegrist, 2010). Nevertheless, medical applications of GM technology in Frewer and Shepherd's (1995) study were perceived to be more beneficial, less risky, and more ethically correct than food applications.

\section{Information Resources about GM Foods}

The resources that people use to receive information regarding GM crops are one of the main factors that might influence their perceptions. Table 8 explains different resources which are being used by the respondents to receive information about GM crops. As shown in the table, considering the possible range (4-20) of the perceptions, the average use of different information resources is very low $(\bar{X}=6.12)$.

\section{[insert Table 8]}

The results show that the most applied information resource is "scientific books and journals", which are "highly" and "very highly" used by one-third (33.6\%) of the respondents, followed by "TV" as the second most applied information resource which is used by $21.7 \%$ of the respondents. The third preferred information resource by the professionals is "internet". This information resource is highly and very highly used by $20.7 \%$ of the respondents. "Newspaper and radio" as two main public media are (highly and very highly) used by only $18.7 \%$ and $7.2 \%$ of the respondents, respectively. Based on the results, therefore, the respondents prefer to develop their knowledge about GM crops mostly by using professional information resources; i.e. scientific books and journals.

The above findings show the importance of "writing media" as the most applied information resource. The findings can be supported by Fritz et al.'s (2003) study that 
showed that the Americans mostly use newspapers, internet, and scientific magazines to develop their knowledge about GM crops. Agricultural students in Wingenbach's (2003) study introduced some courses, laboratories and the scientific members of their faculty as their main reference information resources with regard to GM crops. Some studies (Wheeler 2005; Xi and Harris 2006) showed that agricultural experts mainly use radio, TV, and newspapers to receive information regarding GM crops.

\section{Behavioral Intentions toward GM Foods}

The study also investigated the behavioral intentions of agricultural professionals. From possible range of $4-20$, the average score for benefit perceptions was 13.24 which is around the mean. Table 9 shows the professionals have moderate intentions to use GM crops as the average of behavioral intentions is modest $(\bar{X}=13.24)$.

The results however show that most $(73.1 \%)$ of the professionals are willing to buy and consume these foods as they contain richer nutrients.

\section{[insert Table 9]}

Almost half (47\%) of the respondents "disagree" and "fully disagree" that they buy these products because they are cheaper. In contrast, one-third (33.2\%) of the respondents buy GM foods because of their cheaper price. Less than half (47\%) of the respondents claim that they would try GM foods (at least once) to get to know their taste, even if they knew that these foods might be harmful. As well, more than half (54.4\%) of the respondents would like to buy GM foods, since they believe these foods are produced with less use of pesticide. Additionally, most (80.6\%) of the professionals are highly motivated to get involved in conducting research and extension activities on 


\section{GM crops.}

The above findings are in line with Huang et al.'s (2006) study that showed the Chinese consumers have high intention to buy GM crops even if the price of such crops is higher than the non-GM's. They concluded that the majority of their respondents would buy more GM crops if they are sure that such crops are more resistant to pest, can be stored longer, and have higher quality nutrients. It can therefore be concluded that if consumers are sure about the better quality of GM crops, they would buy these crops despite their higher price compared to the non-GM's (Boccaletti and Moro 2000; Huang et al. 2006; Shehata and Cox 2007).

Comparison of Behavioral Intentions with Regard to Knowledge

In order to compare the impact of knowledge about GM crops on the behavioral intentions of the respondents, a cluster analysis was used to divide agricultural professionals to three groups of knowledge: low-knowledge, mean-knowledge and high-knowledge. The groups were compared with regard to trust in individuals and agencies, perceived benefits, perceived risks, perceived ethics and behavioral intentions. The results are shown in Table 10 .

[insert Table 10]

As shown in the table, there are some significant differences $(\mathrm{F}=8.59 ; \mathrm{P}=0.0001)$ among different levels of the professionals' knowledge (confirmed by ANOVA and LSD). The differences show those professionals who have "high" knowledge about GM crops (12.29), are significantly less willing to buy such foods compared to those who have "low" and "middle" knowledge (13.54 and 13.48, respectively). Pearson 
correlation analysis confirms this finding. The analysis shows when the professionals' knowledge about GM crops increases, their intention to buy such crops decreases $(r=-$ $0.21 ; \mathrm{P} \leq 0.01)$

This finding is confirmed by Wheeler (2005) and Papastefanou et al. (2003) while rejected by Fritz et al. (2003), Hu and Chen (2004) and Soregaroli et al. (2003). Boccaletti and Moro (2000) and Fritz et al. (2003) showed when the consumers' knowledge about GM crops increases, their acceptance of these crops decreases and vice versa.

Factors Influencing Behavioral Intentions

In order to understand how the exogenous variables introduced in the research framework (Fig. 1) can (direct/indirectly) influence the endogenous variable ${ }^{\mathrm{g}}$, a path analysis was run by AMOS software. The results of path analysis are shown in Table 11 and Fig. 2.

[insert Table 11 and Fig. 2]

The direct effects (D.E.) of the perceptions explain that "trust in individuals and agencies" is the most effective factor which has a significant positive effect on the behavioral perceptions of the agricultural professionals to buy GM foods (D.E. = 0.23; $\mathrm{P} \leq 0.01)$. In other words, when the professionals' trust in the individuals and agencies increases, it positively affects their intention to buy GM foods. This finding shows that agencies and individuals (physicians, researchers, policy makers, and the person in charge of shopping in the family) play an important role in creating positive perceptions 
toward GM foods. This means that the respondents, as gatekeepers, try to develop their knowledge about GM foods by trusting the information received from such people and agencies. This finding is confirmed by Boccaletti and Moro (2000) who found that the main reason for the low acceptance of GM foods is "low knowledge" of the individuals whereas those with a higher knowledge are more likely to buy these products. It is also clear that whenever consumers are informed by proper information, they are more willing to pay higher prices in order to benefit from quality improvements. This finding shows the importance of the issues which often prevail over ethical considerations. This may particularly be true whenever the use of biotechnology reduces health risks, such as those caused by the use of pesticides.

The professionals' knowledge about GM foods has a significant negative direct effect on the intention of buying such foods. It means when their knowledge enhances, their intention to buy these foods decreases (D.E. $=-0.19 ; \mathrm{P} \leq 0.01$ ). Indirectly, by influencing individuals' perceptions toward GM foods' benefits, "knowledge" affects behavioral intentions. In other words, when the professionals get more to know about these foods, they probably better understand their disadvantages and therefore they will less be willing to buy GM foods. This finding can be confirmed by Sandoe (2001) who believes when the knowledge about GM foods increases, consumers are more critical in using them. This finding is also supported by Boccaletti and Moro (2000) but rejected by $\mathrm{Hu}$ and Chen (2004) and Soregaroli et al. (2003).

The direct negative effect of knowledge about GM foods on behavioral intention to buy these foods shows that when the agricultural professionals, as gatekeepers, develop their knowledge about GM foods, their awareness toward the risks of these foods increases and therefore, the individuals have more doubts about the GM foods' safety, 
and consequently, their intention to buy these foods decreases. Sandoe (2001) believes when the knowledge increases, people ask more important and reasonable questions which come from their doubt on the foods.

In their study, Chen and $\mathrm{Li}$ (2007) concluded that if people find more advantages for GM foods than disadvantages, they will more be optimistic about using them and therefore more willing to buy the foods. This finding is supported by Trail et al. (2004). Understanding of the advantages has a direct and significant positive effect on the perceptions toward the GM threats. Knowledge also has the same effect on understanding the advantages of GM foods. In other words, increasing knowledge about GM foods can improve the understanding of their (dis)advantages and consequently develop optimistic or pessimistic views about consuming these foods.

Lastly, as discussed in the literature, moral concerns are of importance and do influence people's perception toward gene technology (Connor and Siegrist 2010). In our study however, ethical issues (Table 7) were not recognized as a major concern by the professionals who hold higher level of education than the public, and whose trust in individuals and agencies often prevails them over ethical considerations. In other words, the moral issues, despite their importance, are less understood as a barrier to accept or reject GM foods.

\section{Conclusion and Recommendation}

Overall, the level of knowledge and awareness toward benefits, and trust in information sources, which support developing GM foods, are the most effective factors in the acceptance of these foods. Based on Wheeler's (2005) study, it was expected that the 
professionals, as gatekeepers, were able to correctly judge their knowledge of GM foods as generally the issue is much more familiar and prevalent to them. However, this study showed that the agricultural professionals, despite their high education level, have limited information and knowledge regarding GM foods. It is interesting to note that in contrast to expectation, higher knowledge about GM foods does not lead to higher intention to buy GM foods. It can be concluded that by increasing agricultural professionals' knowledge, their understanding of the GM foods' risks also increases and consequently, they are less willing to buy such foods. It is also important to understand the professionals' concerns about the risks of GM foods. The concerns are mainly about creating new bacteria and viruses; human mutation; a conflict between rich and poor farmers; the transformation of safe species to unsafe; and a threat to environment by using these foods. Such concerns show the importance of producing GM foods with the least aforementioned concerns.

Considering the above conclusions, one can raise a question regarding the future of GM food in Iran. If the intention is to have knowledge based on the diffusion of GM food, successful promotion is unlikely due to the negative impact of knowledge about these foods on behavior intention. The major barrier to promotion of GM crops is concern about their safety for the environment (Nap et al. 2003). Based on our findings, dissemination of current knowledge has a negative impact on intention to buy these foods. It should be realized that the perceptions of the agricultural experts, as gatekeepers, toward GM food has great impact on their research and promotion priorities. Therefore, before acceptance of GM food by the public, it should successfully be passed by the majority of experts. 
Recommendation

To improve the policy and practical framework within which promotion of GM food is practiced, we make the following recommendations. Further research, particularly in the areas of concern to agricultural professionals (as gatekeepers) should be conducted to convince them of the safety of these foods. There is a need for a well defined communication strategy to provide information in such a way that allows individuals to feel adequately and satisfactorily informed about GM foods. Instead of a passive communication strategy which tries to react to the stakeholders' questions on GM foods, an active communication strategy should be launched, in which the government does not wait to receive and react to the questions but should take the initiatives and provide the stakeholders with valid information on GM foods. Current passive and conflicting information on the risks and benefits of GM foods led stakeholders to rely on information shortcuts and to make decisions based on their benefit perception, knowledge and their trust on individuals and agencies. There are different perspectives on the contribution of gene technology to sustainable development and food security (Bazuin et al. 2011). Some studies (Azadi et al. 2011b; ISAAA 2009; Qaim 2003; Uzogara 2000) have emphasized the importance of GM foods in solving the problem of food insecurity and the fact that such an advanced technology cannot be neglected in meeting the growing food demands of increasing population. However, there are concerns about the diffusion of such an innovation in both public and private debates, most importantly, its potential threats on human and environmental health. To lessen these concerns, more risk assessment studies should be carried out by the government. Furthermore, development of trust and knowledge on GM foods accrue when risk 
analysis frameworks are transparent, risk assessment methodologies are objective, all stakeholders are engaged in the risk management process, and risk communication focuses on the consumer. Also, as this study did not ask for the influence of the respondents' religious convictions, future studies could collect and analyze such information to find out their possible correlation with the perceived ethics. A focus on expert-lay discrepancies could also be recommended in the future studies. Focusing on such discrepancies is very important, especially when bearing in mind that no study has been conducted yet on the views of the public in Iran on this issue.

In terms of information content, people wanted to know more about GM risks and benefits, potential long-term societal and personal impacts, and the potential consequences for animal welfare. Therefore, information provided at the workshops, seminars, catalogues, conferences, broadcasting about the prevalence of GM foods should be multi-dimensional. One-dimensional information in favor of the benefits may increase suspicion and reduce adoption rates of these foods.

Because trust in the regulatory institutions and scientists performing genetic engineering exerts a strong effect on perceptions toward the benefits of GM foods, the government should take the responsibility for monitoring the proper functioning of the safety mechanism in producing these foods so as to increase the trust of agricultural professionals and consequently the public. Moreover, the Iranian government should increase transparency in formulating fair laws and communicate more frequently and effectively with consumers. Adequate regulations, constant monitoring, and intensive research are essential to avoiding possible harmful effects from GM food technology. 


\section{References}

Aerni, P. (2001). Assessing stakeholder attitudes to agricultural biotechnology in developing countries. Biotechnology and Development Monitor, 47, 2-7.

Aerni, P. (2005). Stakeholder attitudes towards the risks and benefits of genetically modified crops in South Africa. Environmental Science \& Policy, 8(5), 464-476.

Azadi, H., \& Ho, P. (2010). Genetically modified and organic crops: A review of options for food security. Biotechnology Advances, 28(1), 160-168.

Azadi, H., Talsma, N., Ho, P., \& Zarafshani, K. (2011a). GM crops in Ethiopia: A realistic way to increase agricultural performance? Trends in Biotechnology, 29(1), 6-8.

Azadi, H., Schoonbeek, S., Mahmoudi, H., Derudder, B., De Maeyer, P., \& Witlox, F., (2011b). Organic agriculture and sustainable food production system: Main potentials. Agriculture, Ecosystems \& Environment, 144, 92- 94.

Baker, G. A., \& Burnham, T. A. (2001). Consumer response to genetically modified foods: Market segment analysis and implications for producers and policy makers. Agricultural and Resource Economics, 26(2), 387-403.

Baruch, Y., \& Holtom, B. (2008). Survey response rate levels and trends in organizational research. Human Relations, 61(8), 1139-1160.

Bazuin, S. Azadi, H., \& Witlox, F. (2011). Application of GM crops in Sub-Saharan Africa: Lessons learned from Green Revolution. Biotechnology Advances, 29, 908912.

Boccaletti, S., \& Moro, D. (2000). Consumer willingness-to-pay for GM food products in Italy. AgBioForum, 3(4), 259-267.

Bredahl, L. (2001). Determinants of consumer attitudes and purchase intentions with 
regard to genetically modified foods-results of a cross-national survey. Consumer Policy, 24(1), 23-61.

Bredahl, L., Grunert, G., \& Frewer, L. J. (1998). Consumer attitudes and decision making with regard to genetically engineered food products. A review of literature and a presentation of models for future research. Consumer Policy, 21(3), 251-277.

Cardello, A. V., Schutz, H. G., \& Lesher, L. L. (2007). Consumer perception of foods processed by innovative and emerging technologies: A conjoint study. Innovative Food Science and Emerging Technologies, 8, 73-83.

Chen, M. F., \& Li, H. L. (2007). The consumers' attitude toward genetically modified food in Taiwan. Food Quality and Preference, 18(4), 662-674.

Chern, W. S., Rickertsen, K. Tsuboi, N. \& Fu, T. (2002). Consumer acceptance and willingness to pay for genetically modified vegetable oil and salmon: A multiplecountry assessment. AgBioForum, 5(3), 105-112.

Cohen, J. I., Paarlberg, R. (2004). Unlocking crop biotechnology in developing countries — a report from the field. World Development, 32(9), 1563-77.

Connor, M., Siegrist, M. (2010). Factors influencing people's acceptance of gene technology: the role of knowledge, health expectations, naturalness and social trust. Science Communication, 32(4), 514-538.

Cook, A. J., \& Fairweather, J. R. (2003). New Zealand farmer and grower intentions to use gene technology: results from a survey. AgBioForum, 6(3), 120-127.

Cook, A. J., Kerr, G. N., \& Moore, K. (2002). Attitudes and intentions towards purchasing GM food. Economic Psychology, 23(5), 557-572. 
Costa-Font, M., Gil, J. M., \& Traill W. B. (2008). Consumer acceptance, valuation of and attitudes towards genetically modified food: Review and implications for food policy. Food Policy, 33, 99-111.

Deodhar, S. Y., Ganesh, S., \& Chern, W. S. (2008). Emerging markets for GM foods: A study of consumer's willingness to pay in India. Selected paper prepared for presentation at the American Agricultural Economics Association Annual Meeting, Orlando, Florida, July 27-29.

Egelyng, H. (2000). Managing agriculture biotechnology for sustainable development: The case of Semi-Arid India. International Journal of Biotechnology, 2(4), 342-354 Eurobarometer (2001). Europeans, science and technology in 2001. Fieldwork, 2001.

Eurobarometer (2002). Europeans, science and technology in 2002. Fieldwork, 2002.

Eurobarometer (2004). Attitudes of European citizens towards the environment. Fieldwork, 2004.

Eurobarometer (2005). Europeans, science and technology in 2005. Fieldwork, 2005.

Eurobarometer (2006). GM food: Europeans still see more risks than benefits. 2006: http://www.gmocompass.org/eng/news/stories/227.eurobarometer_europeans_biote chnology.html

Frewer, L., Howard, C., \& Aaron, J. (1998). Consumer acceptance of transgenic crops. Pesticide Science, 52(4), 388-393.

Frewer, L., Lassen, J., Kettlitz, B., Scholderer, J., Beekman, V., \& Berdal, K. G. (2004). Societal aspects of genetically modified foods. Food and Chemical Toxicology, 42(1), 1181-1193.

Frewer, L., Scholderer, J., Downs, C., \& Bredahl, L. (2000). Communicating about the risks and benefits of genetically modified foods: effects of different information 
strategies. MAPP, Aarhu, Working Paper, 71.

Frewer, L. J., \& Shepherd, R. (1995). Ethical concerns and risk perceptions associated with different applications of genetic engineering: interrelationships with the perceived need for regulation of the technology. Agriculture and Human Values, 12(1), 48-57.

Fritz, S., Husmann, D., Wingenbach, G., Rutherford, T., Egger, V., \& Wadhwa, P. (2003). Awareness and acceptance of biotechnology issues among youth, undergraduates, and adults. AgBioForum, 6(4), 178-184.

Grunert, K. G., Bredahl, L., \& Scholder, J. (2003). Four questions on European consumers' attitudes toward the use of genetic modification in food production. Innovative Food Science and Emerging Technologies, 4(4), 435-445.

Grunert, K., Lahteenmaki, L., Nielsen, N., Poulsen, J., Ueland, O., \& Astrom, A. (2000). Consumer perception of food products involving genetic modification: results from a qualitative study in four nordic countries. (Work. Rep. No. 72), MAPP, Aarhus.

Han, J. H., \& Harrison, R. W. (2004). A multinomial logic model of consumer perceptions for biotech food labeling. Selected Paper prepared for presentation at the American Agricultural Economics Association Annual Meeting, Denver, Colorado, $\quad$ August $\quad 1-4, \quad 2004$ : http://ageconsearch.umn.edu/bitstream/20157/1/sp04ha08.pdf

Hansen, J., Holm, L., Frewer, L., Robinson, P., \& Sandøe, P. (2003). Beyond the knowledge deficit: Recent research into lay and expert attitudes to food risks. Appetite, 41, 111-121. 
Hoban, T. (1998). Trends in consumer attitudes about agricultural biotechnology. AgBioForum, 1(1), 3-7.

Hoban, T. (2001). Food industry leaders' perceptions of biotechnology. North Carolina State University, Raleigh, NC.

Hossain, F., Onyango, B., Adelaja, A., Schilling, B., \& Hallman, W. (2002). Public perceptions of biotechnology and acceptance of genetically modified food. Food Policy Institute WP, New Brunswick.

Hossain, F., Onyango, B., Schilling, B., Hallman, W., \& Adelaja, A. (2003). Product attributes, consumer benefits and public approval of genetically modified foods. Consumer Studies, 27(5), 353-365.

Hu, W., \& Chen, K. (2004). Can Chinese consumers be persuaded? The case of genetically modified vegetable oil. AgBioForum, 7(3), 124-132.

Huang, J., Bai, J., Pray, C., \& Tuan, F. (2004). Public awareness, acceptance of and willingness to buy genetically modified foods in China. Rutgers University.

Huang, J., Qiu, H., Bai, J., \& Pray, C. (2006). Awareness, acceptance of and willingness to buy genetically modified foods. Appetite, 46(2), 144-151.

International Service for the Acquisition of Agri-Biotech Applications (2009). Global status of commercialized biotech/GM crops. http://www. ISAAA.org

James, J. (2004). Consumer knowledge and acceptance of agricultural biotechnology vary. California Agriculture, 58(2), 99-105.

King, D. (2007). GM food safer than normal food, government adviser says. The $\begin{array}{llll}\text { Guardian, } & \text { Tuesday } & 27 & \text { November }\end{array}$ http://www.guardian.co.uk/uk/2007/nov/27/foodanddrink.gmcrops

Knight, A. J. (2009). Perceptions, knowledge and ethical concerns with GM foods and 
the GM process. Public Understanding of Science, 18(2), 177-188.

Leonard-Barton, D. (1985). Experts as negative opinion leaders in the diffusion of a technological innovation. Consumer Research, 11, 914-926.

Lobb, A. E., Mazzocchi, M., \& Trail, W. B. (2007). Modeling risk perception and trust in food safety information within the theory of planned behavior. Food Quality and Preference, 18(2), 384-394.

Martinez-Poveda, A., Molla-Bauza, M. B., Campo Gomis, F. J. D., \& MartinezCarrasco, M. L. (2009). Consumer-perceived risk model for the introduction of genetically modified food in Spain. Food Policy, 34(6), 519-528.

Mathison, S. (2001). Ethical analysis of genetically modified crops issue: introduction, summary. http://www.lcsc.edu/ns350/Issues/ corpsethintro.com

Metoyer-Duran, C. (1993). Information gatekeepers. In M. Williams (Ed.). Annual review of information science \& technology. Medford, NJ: Learned Information. 28 111-150.

Moon, W., \& Balasubramanian, S. K. (2001). Public perceptions and willingness-to-pay a premium for non-GM Foods in the US and UK. AgBioForum, 4(3-4), 221-231.

Moseley, B. E. B. (1999). The safety and social acceptance of novel foods. Food Microbiology, 50(1-2), 25-31.

Nap, J-P., Metz, P. L. J., Escaler, M., \& Conner, J. (2003). The release of genetically modified crops into the environment. The Plant Journal, 33, 1-18.

Onyango, B., Govindasamy, R., Hallman, W., Schilling, B., \& Adelajan, A. (2003). Public perceptions of food biotechnology: Uncovering factors driving consumer acceptance of genetically modified food. Food Distribution Research, 34(1), 37-42.

Papastefanou, G., Springer, A., Tsioumanis, S., \& Mattas, K. (2003). Cultural context 
and attitudes towards genetically modified food in Greece and West Germany. http://www.gesis.org/fileadmin/upload/forschung/publikationen/gesis_reihen/zuma_ arbeitsberichte/03_01_gmfood.pdf

Patton, M. L. (2002). Proposing empirical research. A guide to the fundamentals $\left(^{\text {nd }}\right.$ Ed.). Los Angeles: Pyrczak Inc.

Peters, L. D. (2003). Sustainable farming needs bioengineering. http://www.yaledailynews.com/article.asp?AID=23774

Pindstrup-Andersen P., Schibler, E. (2001). Seeds of contention: world hunger and the global controversy over GM crops. Baltimore ML: Johns Hopkins University Press.

Pretty, J. N. (1995). Regenerating agriculture: Policies and practice for sustainability and self reliance. London: Earthscan.

Rasul, G., \& Thapa, G. B. (2003). Sustainability of ecological and conventional agricultural systems in Bangladesh: an assessment based on environmental, economic and social perspectives. Agricultural Systems, 79(3), 327-351.

Retherford, R. D., \& Choe, M. K. (1993). Statistical models for causal analysis. Hoboken, NJ: John Wiley \& Sons, Inc.

Rigby, D. D. (2001). Caceres, Organic farming and the sustainability of agricultural systems. Agricultural Systems, 68, 21-40.

Rogers, E. M. (2003). Diffusion of innovations (5th ed.). New York: The Free Press.

Rogers, E. M., \& Agarwala, R. (1976). Communication in organizations. New York: The Free Press.

Rogers, E. M., \& Kincaid, D. L. (1981). Communication networks: Toward a new paradigm for research. New York: The Free Press.

Sandoe, P. (2001). What is the lesson to be learnt from the controversy about gene 
technology, Report of the first integrated discussion platform, Meeting of the thematic network Entrance Food. Ispra.

Savadori, L., Savio, S., Nicotra, E., \& Rumiati, R. (2004). Expert and public perception of risk from biotechnology. Risk Analysis, 24(5), 1289-1299.

Shehata, S., \& Cox, L. J. (2007). Attitudes of Hawaii consumers toward genetically modified fruits. http://www.ctahr.hawaii.edu/oc/freepubs/pdf/BIO-7.pdf

Sheikhha, M. H., Kalantar, S. M., Vahidi, A. R., \& Faghihi, M. (2006). Public knowledge and perceptions of biotechnology and genetically modified organisms in Iran. Biotechnology, 4(2), 130-136.

Sjöberg, L. (2008). Genetically modified food in the eyes of the public and experts. Risk Management, 10, 168-193.

Siegrist, M. (2000). The influence of trust and perceptions of risks and benefits on the acceptance of gene technology. Risk Analysis, 20(2), 195-204.

Siegrist, M., Cousin, M. E., Kastenholz, H., \& Wiek, A. (2007). Public acceptance of nanotechnology foods and food packaging: The influence of affect and trust. Appetite, 49, 459-466.

Soregaroli, C., Boccaletti, S., \& Moro, D. (2003). Consumer's attitude towards labeled and unlabeled GM food products in Italy. International Food and Agribusiness Management Review, 6(2), 111-127.

Teisl, M. F., Fein, S. B., \& Levy, A. S. (2009). Information effects on consumer attitudes toward three food technologies: organic production, biotechnology, and irradiation. Food Quality and Preference, 20(8), 586-596.

Thompson, P. (1999). The ethics of truth-telling and the problem of risk. Science and Engineering Ethics, 5(4), 489-510. 
Tornatzky, L. B., \& Fleisher, M. (1990). The processes of technological innovation. Lexington, MA: Lexington Books, D.C. Heath and Company.

Uzogara, S. G. (2000). The impact of genetic modification of human foods in the $21^{\text {st }}$ century: a review. Biotechnology Advances, 18(3), 179-206.

Verdurme, A., \& Viaene, F. (2003). Consumer attitudes towards genetically modified food. Qualitative Market Research, 6(2), 95-11.

Wheeler, S. (2005). Factors influencing agricultural professionals' attitudes towards organic agriculture and biotechnology. Australia: University of South Australia. http://een.anu.edu.au/e05prpap/wheeler.pdf.

Wheeler, S. (2008). What influences agricultural professionals' views towards organic agriculture? Ecological Economics, 65(1), 145-154.

Wheeler, S. (2009). Exploring the influences on Australian agricultural professionals' genetic engineering beliefs: An empirical analysis. Technology Transfer, 34(4), $422-439$.

Wingenbach, G. J., Rutherford, T. A., \& Dunsford, D. W. (2003). Agricultural communications students' awareness and perceptions of biotechnology issues. Agricultural Education, 44(4), 80-93.

Xi, C., \& Harris, R. (2006). Consumer attitudes toward genetically modified foods: A U.S-China risk-benefit perception comparison. http://web.cenet.org.cn/upfile/92230.pdf

Zhong, F., Marchant, M. A., Ding, Y., \& Lu, K. (2002). GM foods: a Nanjing case study of Chinese consumers' awareness and potential attitudes. AgBioForum, 5(4), 136-144. 


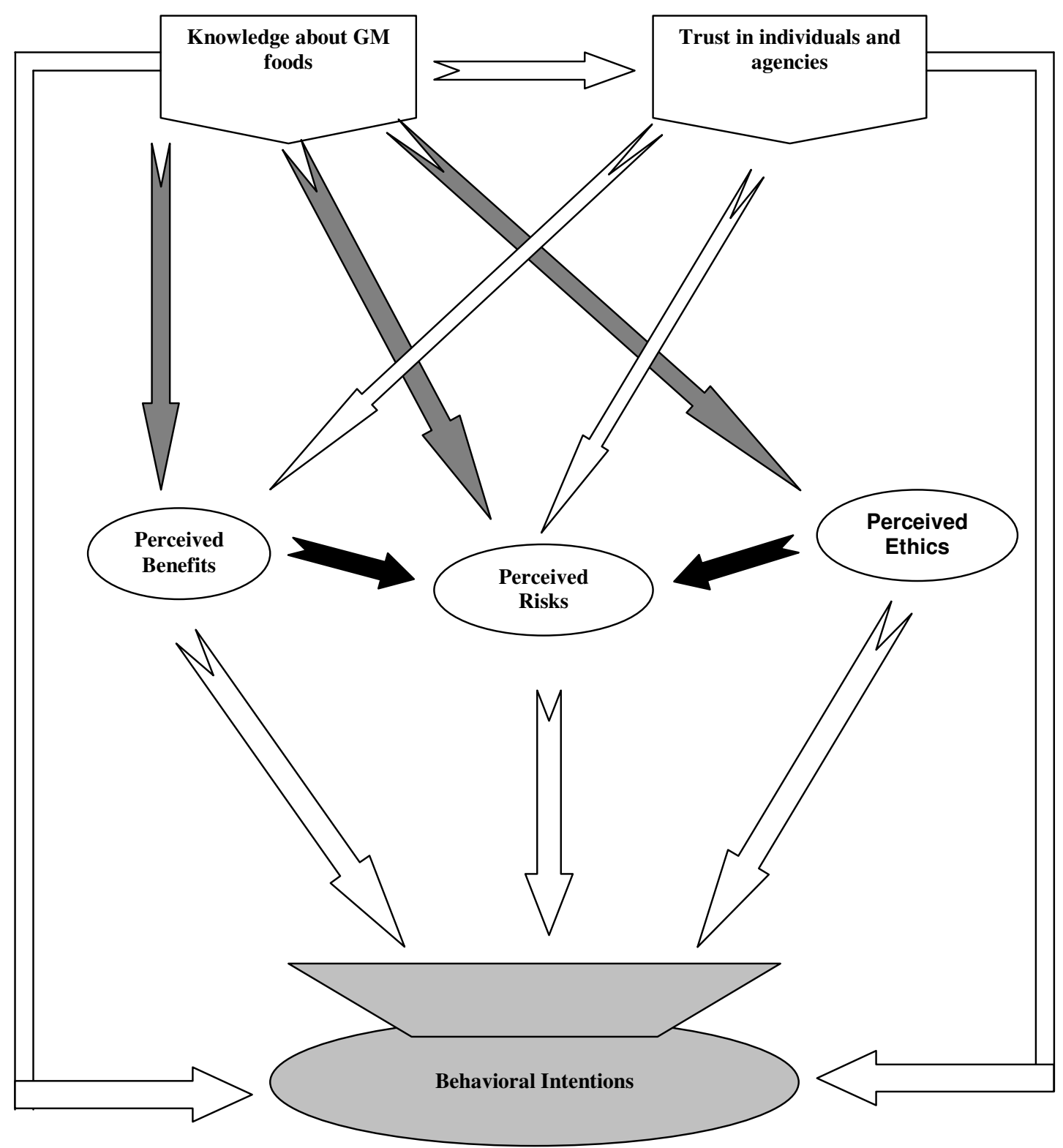

Fig. 1. Theoretical framework: factors influencing the agricultural professionals' behavioral intentions towards GM foods. 


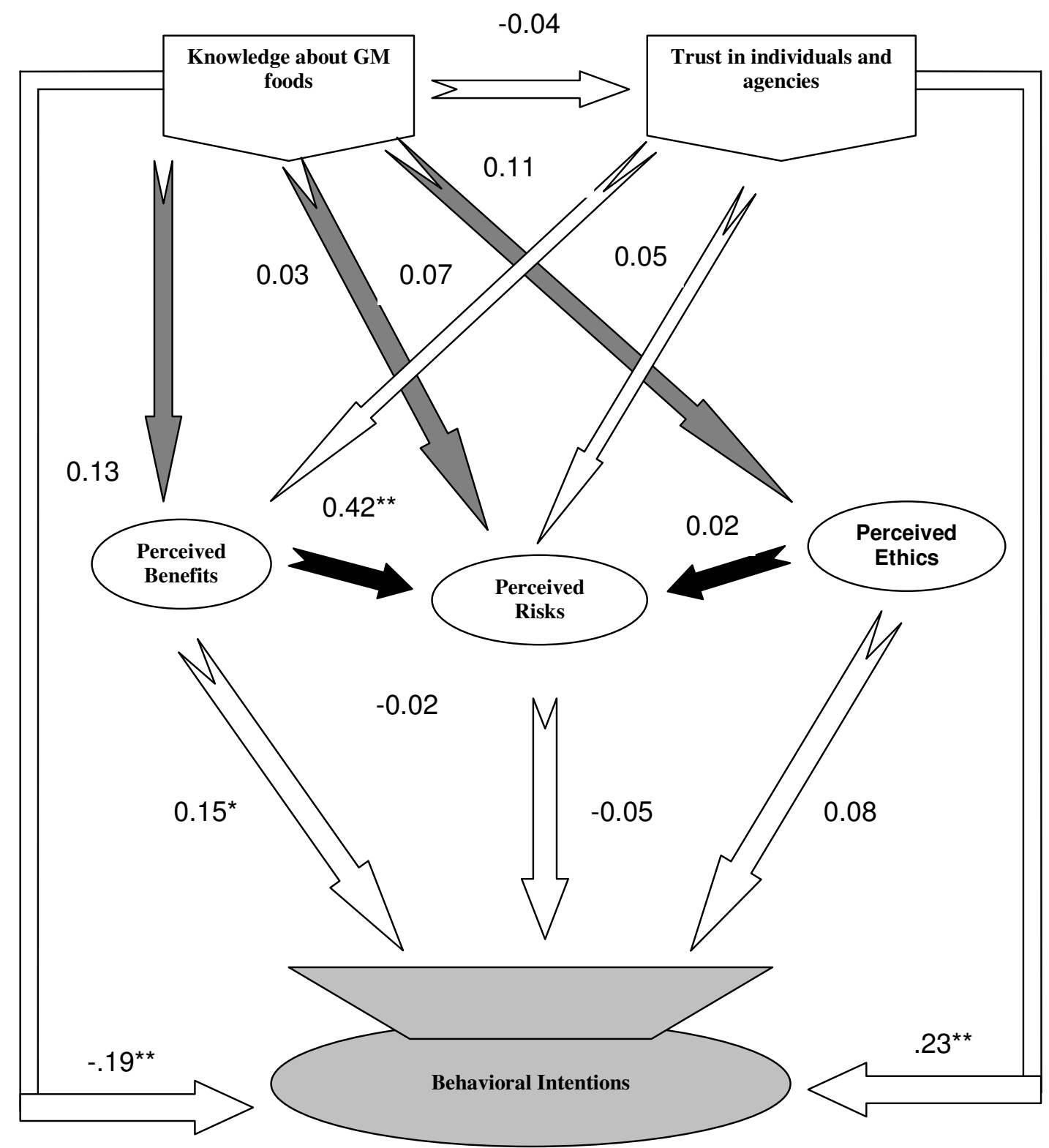

Fig. 2. Path diagram results: factors influencing the agricultural professionals' behavioral intentions towards GM foods (**: P $\leq 0.01)$. 
Table 1. Cronbach's alpha for the main scales of the study.

\begin{tabular}{lc}
\hline \multicolumn{1}{c}{ Scales } & $\begin{array}{c}\text { Alpha's } \\
\text { coefficients }\end{array}$ \\
\hline Knowledge about GM foods & 0.56 \\
Trust in individuals and agencies & 0.68 \\
Perceived Benefits & 0.76 \\
Perceived Risks & 0.92 \\
Perceived Ethics & 0.65 \\
Information resources & 0.78 \\
Behavioral Intentions & 0.43 \\
\hline
\end{tabular}


Table 2. Demographic information of the respondents.

\begin{tabular}{|c|c|c|c|}
\hline $\begin{array}{l}\text { Demographic } \\
\text { attributes }\end{array}$ & Category & Frequency & Percentage \\
\hline \multirow{3}{*}{ Age } & $18-35$ & 166 & 66.1 \\
\hline & $36-50$ & 77 & 30.7 \\
\hline & $51-76$ & 8 & 3.2 \\
\hline \multirow{3}{*}{ Gender } & Male & 235 & 88.7 \\
\hline & Female & 30 & 11.3 \\
\hline & $\mathrm{AD}$ & 20 & 8.7 \\
\hline \multirow{3}{*}{ Education } & $\mathrm{BS}$ & 136 & 58.9 \\
\hline & MS & 58 & 25.1 \\
\hline & $\mathrm{PhD}$ & 17 & 7.3 \\
\hline \multirow{4}{*}{ Position } & Extension expert & 24 & 9.4 \\
\hline & Agricultural expert & 161 & 62.6 \\
\hline & Manager & 10 & 3.9 \\
\hline & Researcher & 62 & 24.1 \\
\hline \multirow[b]{2}{*}{ Job experience } & $<14$ years & 131 & 49.2 \\
\hline & $>14$ year & 135 & 50.8 \\
\hline \multirow{4}{*}{$\begin{array}{l}\text { Household Monthly } \\
\text { Income in dollars }\end{array}$} & $<600$ & 122 & 62.2 \\
\hline & $600-1100$ & 54 & 27.6 \\
\hline & $1100-2000$ & 19 & 9.7 \\
\hline & $>2000$ & 1 & 0.5 \\
\hline
\end{tabular}


Table 3. The awareness and knowledge of the respondents toward GM foods.

\begin{tabular}{|c|c|c|c|}
\hline Items & $\begin{array}{l}\text { True } \\
(\%)\end{array}$ & $\begin{array}{l}\text { False } \\
(\%)\end{array}$ & $\begin{array}{l}\text { Correct answers } \\
(\%)\end{array}$ \\
\hline 1. GM crops are the same as conventionally cross-bred crops. & 76.2 & 23.8 & 23.8 \\
\hline 2. GM crops are the same as organic crops. & 36.3 & 63.7 & 63.7 \\
\hline $\begin{array}{l}\text { 3. GM crops are produced by taking genes from plant species } \\
\text { and transferring them into plants. }\end{array}$ & 66.5 & 33.5 & 66.5 \\
\hline $\begin{array}{l}\text { 4. Some preferred features can be created on products by } \\
\text { gene transfers. }\end{array}$ & 90.5 & 9.5 & 90.5 \\
\hline 5. Non-GM foods do not contain genes, while GM foods do. & 37.3 & 62.7 & 62.7 \\
\hline 6. It is impossible to transfer animals' genes into plants. & 66.7 & 33.3 & 33.3 \\
\hline 7. Tomato modified with fish genes would taste fishy. & 56.1 & 43.9 & 43.9 \\
\hline 8. GM foods can be distinguished from non-GM foods. & 35.6 & 64.4 & 64.4 \\
\hline 9. All processed foods are made using GM products. & 19.5 & 80.5 & 80.5 \\
\hline $\begin{array}{l}\text { 10. Recently Iran is also applying GM technology to produce } \\
\text { crops. }\end{array}$ & 65.5 & 34.5 & 65.5 \\
\hline
\end{tabular}

Total knowledge about GM crops: $\bar{X}=11.92, \mathrm{SD}=4.01$, Possible range $=0-20$. 
Table 4. The percentage of the respondents' trust in individuals and agencies.

\begin{tabular}{|c|c|c|c|c|c|c|}
\hline Trust in individuals and agencies & $\begin{array}{l}\text { Fully } \\
\text { disagree }\end{array}$ & Disagree & $\begin{array}{l}\text { Don't } \\
\text { know }\end{array}$ & Agree & $\begin{array}{l}\text { Fully } \\
\text { agree }\end{array}$ & Rank \\
\hline $\begin{array}{l}\text { 1. I trust scientists and researchers are aware of } \\
\text { their responsibilities in doing genetic } \\
\text { engineering. }\end{array}$ & 0.4 & 21.5 & 14.6 & 55.2 & 8.4 & 4 \\
\hline $\begin{array}{l}\text { 2. Agricultural decision makers care only } \\
\text { economic benefits rather than the individuals' } \\
\text { health. }\end{array}$ & 9.5 & 43.7 & 20.2 & 20.5 & 6.1 & 6 \\
\hline $\begin{array}{l}\text { 3. I trust the government ensures the safety of } \\
\text { GM foods. }\end{array}$ & 1.5 & 11.1 & 22.9 & 54.6 & 9.9 & 3 \\
\hline $\begin{array}{l}\text { 4. Surely, there is no worry to consume GM } \\
\text { foods if the Standard Institute confirms their } \\
\text { safety. }\end{array}$ & 1.5 & 18.6 & 25.9 & 49.4 & 4.6 & 5 \\
\hline $\begin{array}{l}\text { 5. I am sure that the person in charge of } \\
\text { shopping in the family gives more priority to the } \\
\text { family's health than the products' price or other } \\
\text { features. }\end{array}$ & 0.8 & 17.5 & 8.4 & 45.2 & 28.1 & 1 \\
\hline $\begin{array}{l}\text { 6. I am sure that physicians take much care of } \\
\text { the community's health and therefore their } \\
\text { opinion about GM crops is very important for } \\
\text { me. }\end{array}$ & 1.9 & 10.3 & 14.5 & 53.4 & 19.8 & 2 \\
\hline $\begin{array}{l}\text { 7. The main goal of the Agricultural Support } \\
\text { Services Company is to secure food supply } \\
\text { rather than food safety. }\end{array}$ & 3.4 & 31.3 & 26.8 & 30.6 & 7.9 & 7 \\
\hline $\begin{array}{l}\text { 8. Food dealers care only economic benefits } \\
\text { rather than the consumers' health. }\end{array}$ & 0.8 & 10.6 & 16.7 & 46.2 & 25.8 & 9 \\
\hline $\begin{array}{l}\text { 9. The main goal of the policy makers is food } \\
\text { security for the growing population rather than } \\
\text { food safety. }\end{array}$ & 6.8 & 37.9 & 27.7 & 20.8 & 6.8 & 8 \\
\hline
\end{tabular}
Total trust in individuals and agencies: $\bar{X}=13.16, \mathrm{SD}=2.30$, Possible range $=4-20$. 
Table 5. The percentage of the respondents' perception toward GM foods' benefits.

\begin{tabular}{|c|c|c|c|c|c|}
\hline GM foods' benefits & $\begin{array}{l}\text { Fully } \\
\text { disagree }\end{array}$ & Disagree & $\begin{array}{l}\text { Don't } \\
\text { know }\end{array}$ & Agree & $\begin{array}{l}\text { Fully } \\
\text { agree }\end{array}$ \\
\hline 1. Higher environmental protection. & 3.1 & 17.6 & 36.3 & 38.5 & 4.6 \\
\hline 2. Less production costs. & 0.8 & 28.1 & 35 & 32.3 & 3.8 \\
\hline 3. Less use of chemical inputs. & 1.6 & 10.5 & 24.6 & 54.3 & 9 \\
\hline 4. Higher yields. & 0.4 & 6.2 & 27.9 & 57.4 & 8.1 \\
\hline 5. Improving seeds' quality. & 1.2 & 8.8 & 26.2 & 56.2 & 7.7 \\
\hline 6. Decreasing growth season length. & 0.8 & 6.6 & 49 & 37.8 & 5.8 \\
\hline 7. Longer storage shelf-time. & 0.4 & 6.9 & 19.8 & 60.3 & 12.6 \\
\hline 8. Higher dry resistance. & 0 & 11.2 & 22.8 & 60.2 & 5.8 \\
\hline 9. Higher nutrients' quality. & 0 & 2.7 & 15.2 & 65.9 & 16.3 \\
\hline 10. Higher quality of foods. & 1.5 & 20 & 61.2 & 15.4 & 1.9 \\
\hline 11. Higher pest resistance. & 0.4 & 4.6 & 17.5 & 70.3 & 7.2 \\
\hline
\end{tabular}
Total benefit perception: $\bar{X}=14.07, \mathrm{SD}=1.33$, Possible range $=4-20$. 
Table 6. The percentage of the respondents' perceptions toward GM foods' risks.

\begin{tabular}{|c|c|c|c|c|c|}
\hline GM foods' risks & $\begin{array}{l}\text { Fully } \\
\text { disagree }\end{array}$ & Disagree & $\begin{array}{l}\text { Don't } \\
\text { know }\end{array}$ & Agree & $\begin{array}{l}\text { Fully } \\
\text { agree }\end{array}$ \\
\hline 1. Threatening natural genetic balance. & 4.6 & 37.9 & 37.9 & 18 & 1.5 \\
\hline 2. Transforming safe species to unsafe. & 0.8 & 3 & 17.3 & 68 & 10.5 \\
\hline 3. Creating mutation in human genes. & 1.9 & 16 & 43.5 & 34.4 & 4.2 \\
\hline 4. Changing life to computerized information. & 0.4 & 0.4 & 12.9 & 73.5 & 12.9 \\
\hline 5. Increasing human resistance to antibiotics. & 1.9 & 20.8 & 35.6 & 38.6 & 3 \\
\hline 6. Threatening useful insects. & 3.1 & 26.4 & 41.8 & 26.8 & 1.9 \\
\hline 7. Creating new bacteria and viruses. & 0.4 & 3.4 & 11.1 & 72.8 & 12.3 \\
\hline $\begin{array}{l}\text { 8.Increasing the gap between developed and } \\
\text { developing countries. }\end{array}$ & 2.3 & 21.8 & 51 & 23.8 & 1.1 \\
\hline 9. Undesired cross-pollination. & 2.7 & 24 & 47.7 & 24.4 & 1.1 \\
\hline
\end{tabular}
Total risk perception: $\bar{X}=13.27, \mathrm{SD}=1.31$, Possible range $=4-20$. 
Table 7. The percentage of the respondents' perceptions about GM foods' ethics.

\begin{tabular}{|c|c|c|c|c|c|}
\hline GM foods' ethics & $\begin{array}{l}\text { Fully } \\
\text { disagree }\end{array}$ & Disagree & $\begin{array}{l}\text { Don't } \\
\text { know }\end{array}$ & Agree & $\begin{array}{l}\text { Fully } \\
\text { agree }\end{array}$ \\
\hline $\begin{array}{l}\text { 1. Gene manipulation is interfering in God's } \\
\text { creation and should not be permitted. }\end{array}$ & 30.6 & 53.2 & 11.3 & 4.2 & 0.8 \\
\hline $\begin{array}{l}\text { 2. If there were any better way for crops to be } \\
\text { created, God would create them in that way. }\end{array}$ & 23 & 48.3 & 19.6 & 7.5 & 1.5 \\
\hline $\begin{array}{l}\text { 3. One of the main reasons for the current } \\
\text { crises is gene manipulation. }\end{array}$ & 21.4 & 49.6 & 20.2 & 7.3 & 1.5 \\
\hline $\begin{array}{l}\text { 4. Gene manipulation is not ethic as it might } \\
\text { create some disorders in both human and } \\
\text { animals. }\end{array}$ & 2.3 & 25.6 & 33.8 & 28.6 & 9.8 \\
\hline $\begin{array}{l}\text { 5. Producing high quality animal products } \\
\text { through GM technology is not ethical if the } \\
\text { products hurt them. }\end{array}$ & 0.4 & 8.3 & 22.3 & 51.1 & 17.8 \\
\hline $\begin{array}{l}\text { 6. Consuming lamb products is not religiously } \\
\text { permitted if they are produced by gene transfer } \\
\text { from pork. }\end{array}$ & 6.1 & 11.8 & 38 & 25.9 & 18.3 \\
\hline $\begin{array}{l}\text { 7. Producing } \mathrm{GM} \text { foods is ethically acceptable } \\
\text { as they reduce poverty, hunger, and } \\
\text { malnutrition. }\end{array}$ & 5.3 & 21.4 & 37.6 & 28.2 & 7.5 \\
\hline
\end{tabular}

Total GM ethics: $\bar{X}=12.87, \mathrm{SD}=2.15$, Possible range $=4-20$. 
Table 8. The percentage of the respondents' perception toward information resources.

\begin{tabular}{|c|c|c|c|c|c|}
\hline Information resources & Not at all & Very low & Low & High & Very high \\
\hline 1. Internet & 38.5 & 38.5 & 23 & 15.5 & 5.2 \\
\hline 2. Radio & 34.5 & 22.9 & 35.3 & 6 & 1.2 \\
\hline 3. Television & 22.9 & 19.8 & 35.6 & 17.4 & 4.3 \\
\hline 4. Newspaper & 24.2 & 20.6 & 36.5 & 15.9 & 2.8 \\
\hline 5. Scientific books and journals & 15.1 & 18.1 & 33.2 & 27 & 6.6 \\
\hline $\begin{array}{l}\text { 6. Seminars, conferences, symposiums, } \\
\text { workshops,... }\end{array}$ & 41.3 & 19 & 25.1 & 11.3 & 3.2 \\
\hline $\begin{array}{l}\text { 7. Scientific members in agricultural } \\
\text { colleges }\end{array}$ & 34.9 & 13.9 & 31.3 & 14.3 & 5.6 \\
\hline 8. Products' label & 58.6 & 15.6 & 18.9 & 5.7 & 1.2 \\
\hline 9. Other colleagues & 31.2 & 23.2 & 33.6 & 9.2 & 2.8 \\
\hline 10. Physicians & 55.1 & 19.6 & 15.1 & 7.3 & 2.9 \\
\hline 11. NGOs & 50.4 & 21.5 & 22 & 5.3 & 0.8 \\
\hline 12. Other sources & 36.5 & 20.6 & 36.5 & 15.9 & 2.8 \\
\hline
\end{tabular}

Total information resource: $\bar{X}=6.12, \mathrm{SD}=3.92$, Possible range $=4-20$. 
Table 9. The percentage of the respondents' behavioral intentions.

\begin{tabular}{|c|c|c|c|c|c|}
\hline Behavioral intentions & $\begin{array}{l}\text { Fully } \\
\text { disagree }\end{array}$ & Disagree & $\begin{array}{l}\text { Don't } \\
\text { know }\end{array}$ & Agree & $\begin{array}{l}\text { Fully } \\
\text { agree }\end{array}$ \\
\hline $\begin{array}{l}\text { 1. If the nutrients of GM crops are more than non- } \\
\text { GM, I will buy them. }\end{array}$ & 1.5 & 9.1 & 16.3 & 62.1 & 11 \\
\hline $\begin{array}{l}\text { 2. If GM crops are cheaper than non-GM, I will buy } \\
\text { them. }\end{array}$ & 6.9 & 40.1 & 19.8 & 30.9 & 2.3 \\
\hline 3. I am very eager to buy non-GM crops. & 1.5 & 26.8 & 37.2 & 28 & 6.5 \\
\hline $\begin{array}{l}\text { 4. As an agricultural expert, I would like to be } \\
\text { involved in conducting research and extension } \\
\text { activities on GM crops. }\end{array}$ & 0 & 7.2 & 12.2 & 58.2 & 22.4 \\
\hline $\begin{array}{l}\text { 5. Even if I knew that GM crops are harmful, I } \\
\text { would try them once to get to know their taste. }\end{array}$ & 12.2 & 26.7 & 14.1 & 42 & 5 \\
\hline $\begin{array}{l}\text { 6. Since GM crops are produced by less use of } \\
\text { pesticide, I would like to buy them. }\end{array}$ & 1.9 & 12.3 & 31.4 & 45.6 & 8.8 \\
\hline
\end{tabular}

Total behavioral intentions: $\bar{X}=13.24, \mathrm{SD}=1.84$, Possible range $=4-20$. 
Table 10. Comparison of the respondents' knowledge with their behavioral intentions.

\begin{tabular}{llllll}
\hline Criteria & \multicolumn{3}{c}{ Knowledge } & F & \multirow{2}{*}{ Sig. } \\
\cline { 2 - 4 } & Low & Mean & High & & \\
\hline Behavioral intentions $\dagger$ & $13.54 \mathrm{~b}$ & $13.48 \mathrm{~b}$ & $12.29 \mathrm{a}$ & 8.59 & 0.00 \\
Trust & 12.87 & 13.33 & 13 & .96 & 0.38 \\
Benefit perceptions & 13.86 & 14.04 & 14.36 & 2.04 & 0.13 \\
Risk perceptions & 13.33 & 23.11 & 13.54 & 2.18 & 0.11 \\
Ethical perceptions & 12.43 & 13.08 & 13.08 & 2.21 & 0.11 \\
\hline
\end{tabular}

$\dagger$ Common letters show non-significant mean (estimated by LSD, $\mathrm{P} \leq 0.05$ ). 
Table 11. Path analysis coefficients of the exogenous and endogenous variables (estimated by AMOS).

\begin{tabular}{lccccc}
\hline Variables & $\begin{array}{c}\text { Direct } \\
\text { effect }\end{array}$ & $\begin{array}{c}\text { Indirect } \\
\text { effect }\end{array}$ & $\begin{array}{c}\text { Non-causal } \\
\text { effect }\end{array}$ & $\begin{array}{c}\text { Total direct } \\
\text { effect }\end{array}$ & $\begin{array}{c}\text { Correlation } \\
\text { coefficient }\end{array}$ \\
\hline Knowledge about GM foods & $-.19^{* *}$ & .03 & -.04 & -.15 & $-.19^{* *}$ \\
Trust in individuals and agencies & $.23^{* *}$ & .009 & .03 & .24 & $.27^{* *}$ \\
GM foods benefits perceptions & $.15^{*}$ & .004 & .02 & .13 & $.13^{*}$ \\
GM foods risks perceptions & .02 & .000 & .04 & -.01 & .03 \\
GM foods ethical perceptions & .08 & .003 & -.02 & .08 & .06 \\
\hline
\end{tabular}

$* \mathrm{P} \leq 0.05$

$* * \mathrm{P} \leq 0.01$

\footnotetext{
${ }^{a}$ In this paper, consumers are excluded from farmers.

b Please note that the authors are aware of focusing on the "professionals' attitudes" (as for this study) rather than consumers' perceptions toward GM foods when providing the literature review, however, the main reason to discuss consumers' attitudes is the fact that most of the available published literature on attitude studies toward GM crops has focused on the public and consumers rather than experts' attitudes. Indeed, it has been one of our main reasons to conduct this study and contribute to understanding the experts' attitudes toward GM foods. Furthermore, we have treated the experts as consumers and this is another reason why the literature has focused on consumers.

${ }^{c}$ At the first stage of our data analysis we investigated the difference between the subpopulations (experts and researchers); although there were some differences, the magnitude of the differences was rather low and non-significant. This was the reason to lump the subpopulation together.

${ }^{d}$ The agricultural experts are those who work in the centers as an advisor. In case local farmers get technical problems, they come to the Rural Services Centers and receive advice from the experts. There are two major differences between such experts and agricultural extensions agents: the experts are high educated (university level) specialized persons in a specific discipline/crop while the agents are not necessarily high educated and specialized persons who normally give general advice which might include all agricultural disciplines/crops. Furthermore, the experts normally stay and work in the centers while the agents work out of the centers directly with the farmers. If farmers need specific advice, they might be directed by the agents to visit a specific expert in the centers.

${ }^{\mathrm{e}}$ Each scale includes several perception questions which each had an ordinal ranking answer (from 1-5). The summation of the answers to each scale was

${ }^{\mathrm{f}}$ Our further analyses show that there is no significant difference among those respondents who hold invalid knowledge in this regard.

${ }^{\mathrm{g}}$ In path analysis, the independent and dependent variables are respectively called exogenous and endogenous variables (Retherford and Choe 1993).
} 